\title{
VASILE LATIȘ - POETUL ORFIC ȘI ORACULAR
}

\section{George ACHIM*}

\section{Vasile Latiș - an Orphic and Oracular Poet}

\begin{abstract}
Poet, ethnologist and anthropologist, with clear inclinations for philosophy, especially the type of philosophy linked to the meditation on language, a teacher as well, Vasile Latis has proven very well to be the representative of a high form of Transylvanian scholar, rooted in the relentless search for the way of things and the primordial meaning of things.

In an oracular style, orphic and somehow bleak, Latis manages to bring forward in a natural manner the figure of the profound and inspired person, the one who saw and knows and managed to reach the essences, descending to roots and archetypes - categories that are very present not only in his lyrical work but also in his scientific works.
\end{abstract}

Keywords: poet, ethnologist, anthropologist, philosopher, archetype, oracular, orphism

Poet, etno-antropolog, nu întru totul filosof, dar ins cu nedezminţite înclinații spre filosofare - îndeosebi spre cea ținând de meditaţia asupra limbajului - profesor de vocație, în stare să producă un adevărat spectacol al oralităţii ex-cathedratice inspirate, Vasile Latiș a ilustrat prodigios o formă înaltă, genuină, de cărturărism ardelenesc, temeinic și bine asimilat, bazat pe știință de carte și pe permanenta căutare a rostului lucrurilor și a sensurilor originare.

În particularul și inefabilul ființei sale, omul era greu de prins într-o formulă unică, pentru că îngemăna, aparent paradoxal, ingenuități deconcertante și vehemențe aiuritoare, o blândețe aparent resemnată, de toamnă târzie, însorită și calmă, laolaltă cu răvășiri tenebroase ale ființei sale și un energetism personal, magnetic, clocotitor, în stare să te lase mut de uimire.

Oracular, orfic și vag neguros, Latiș reușea să impună în mod natural figura omului profund, inspirat, acela care a văzut și știe, tocmai pentru că, punând pe cât se poate contingentul între paranteze, a căutat să ajungă la esențe, coborând către rosturi, obârșii și izvoare (categorii foarte prezente obsesiv aproape! - nu numai în lirica lui, dar chiar și în opera științifică), în căutarea unor arhei constitutivi ai viețuirii și ai limbajului.

\footnotetext{
* Prof. univ. dr., Departamentul de Filologie şi Studii Culturale, Facultatea de Litere, Universitatea Tehnică Cluj-Napoca, str. Victoriei, nr. 76, Baia Mare (george.achim@cunbm.utcluj.ro).
} 
În absența unui sistem de filosofare organic articulat, proiectata epură cogitativă a lui Latiș, ținând de drumul său spre căutarea originarului, rămâne fatalmente fragmentară și eteroclită, deși luate în sine, în doze mici, considerentele sale formulate în spirit noician despre virtuțile filosofice și ontologice ale rostirii românești sau cele despre configurarea arhaic-genuină a noțiunilor de spațiu și timp, nu sunt lipsite de originalitate și de o fervoare ideatic-asociativă spectaculoasă.

Cultivat de către prieteni ori emuli și proclamat drept un ins special, înțelept și „hăruit”, textualizând cu incriptări sapiențiale și uzând de formulări tenebros paradoxale, Vasile Latiș și-a exersat o retorică proprie, ușor încețoșată, consumată îndeosebi în oralitate ori stil epistolar și în fulgurații de cugetare. Ea vizează configurarea - în spirit vulcănescian, de data aceasta - unei dimensiuni arhaic țărănești a existenței, ori apropierea de categorii sau marginalii ontologice (ființă și non-ființă, increatul, neantul, dublul existențial, etc.). Sunt în fapt tot atâtea aporii și interogaţii personale, multe dintre ele simple note de lectură, glosări pe marginea unor texte filosofice sau avântate considerații epistolare, în general emise pe un ton grav și ceremonios al scriiturii, adesea sentențios și apodictic. Ton cu efecte studiate, pendulând între nuanțe de smerenie blândă, țăănească, în rostiri de sotto-voce și inflexiuni grave, metafizice, psalmodiate sacerdotal. Are conștiința - ușor exacerbată - a unicității sale ca făptură cugetătoare, ba chiar orgoliul, din care nu excludem o nuanță de histrionism, al hermeneutului și al deschizătorului de poteci ori al căutătorului de sensuri ultime, validate prin trăire personală directă și experiență-limită. În lipsa unui jurnal sau a unor studii temeince de gen, suntem obligați să dăm credit doar epistolierului ce mărturisește despre laboratorul său de creație, al cărui narativ se încarcă adesea de exaltări poetico-patetice, ca atunci când, de pildă, vorbește într-o scrisoare către un prieten ${ }^{1}$ despre ipoteticul Efect Latiș, concept îndeajuns de metaforic și de vag pentru a fi decisiv înclinaţi să-1 atribuim mai degrabă poetului, aflat într-un moment de ,,inaripare” a inspirației, decât cugetătorului ori iubitorului de filosofie: „Torna, torna, fratre, s-ar fi strigat... Dar eu am mers mult prea departe... și nu mă pot intoarce. $N$-am cum. De profundis clamavi... dar eu de-n zadar am strigat... Am crezut - din orgoliu şi demonie, pesemne! Că eu, da, Eu pot să merg oricât de departe, până la căpăt de capăt. Ce capăt? Întru...Și am mers. Ar trebui să pretind că de acum înainte și când n-o să mai fiu să se numească EFECTUL LATIȘ, așa cum un anumit lucru se numește Efectul Stendhal. Și mi-e groază de mine. Iar uneori: scârbă. Imbrăcată cămașa cea de jar sau tras pe roată... da, uneori visez la suferințe și mai mari (...). Mi-am scuturat părinții până-n rădăcini, toți, rânduri, și Mama se-ngrozește de mine. Și nu

\footnotetext{
${ }^{1}$ Viaţa de aer - epistolar Vasile Latiş - Gavril Ciuban, Editura Grinta, Cluj-Napoca, 2011.
} 
e nimic de făcut. Da, sunt bolnav rău de tot, Prietene! Mare e nebunia. Mai mare durerea și, cuprinzându-le pe-amândouă, mai cumplită! Și uneori simt nevoia să mă purific ca după omor!'”

$\mathrm{Nu}$ putem ști ce stări ori experiențe atroce vor fi ocazionat aceste confesiuni neguros daimonice, mărturia unei propensiuni faustice de fapt, dar ele sunt o mărturie elocventă despre turmentul interior și despre magmele sufletești, în permanentă ebuliție, ale unui spirit de particulară apertură, cu pulsiuni metafizice nedezmințite, cu profunzimi de cugetare și mărturisite iluminări interioare, dar păstrând, în același timp, stigmatul unei neașezări structurale, a lipsei de coagulare interioară organică, ceea ce efavorizează izbucniri ideatice, sporadice, în locul fluxului de cugetare unitar. Poate că impresia de miscellaneu, de laborator sau atelier de creație insuficient ordonat, pe care o lasă opera poetică a lui Latiş, vine tocmai din acest blestem al fragmentarității care dă seama mai degrabă despre posibil și virtualitate, decât despre împlinirea gândului în opera propriu-zisă.

Despre virtualitate, ca „latență a Absolutului”, și despre prodigioasele resurse de intelect și simțire ale tânărului Latiș, doar în parte translaminate în opera acestuia, vorbea într-un emoționant panegiric, criticul Gheorghe Grigurcu ${ }^{2}$, colegul său de odinioară de la Filologia clujeană: „De$o$ uluitoare subtilitate a ideii, de-o sensibilitate $\mathrm{cu}$ incomensurabile disponibilități, insetat de cultură, trăind frenetic într-o zonă idealăa, îmi dădea sentimentul că îi era ursit a se așeza în vecinătatea unor astre de primă mărime, a unor Cioran, Mircea Eliade, Noica, dar n-a fost să fie! Să fi făcut parte din speța acelor genialoizi orali, mistuiți in bună parte de anonimat, pe care î admira Cioran, găsindu-se oarecum vinovat că $i$-a «depășit» prin celebritate? (...) N-am intâlnit în întreaga-mi viață un om mai apt de a recepta cele mai fine vibrații ale ființei, în cazul său sub semnul amărăciunii precoce, a neîmplinirii timpurii, a dezastrului ce se afla chiar în misterioasele sale virtualităti."

Prezența întru totul particulară a autorului făcea ca mirajul și fascinația ipoteticelor „,păduri ce-ar fi putut să fie” acelea pe care criticul le evocă în omagiul său postum, să acționeze subiacent, narcotic aproape, asupra auditoriului, înfășurându-l într-un fuior de rostire blândă, cu imprevizibile accente grave, hieratice ori de metru orfic, proprii înțeleptului ori teosofului, în orice caz aceluia care a aflat și cunoaște adevăruri care celorlalţi le rămân inaccesibile. Purtând pe chip, fixată cu multă măiestrie, figura inițiatului Latiș se dezvăluia și se construia în același timp ca un personaj, fără îndoială consistent și original, dar și de o frapantă stranietate.

Destinul poetic al lui Vasile Latiş seamănă într-un fel cu omul însuşi: ciudat, contorsionat, imprevizibil. Creatorul avea îngemănări indestructibile,

\footnotetext{
${ }^{2}$ Gheorghe Grigurcu, La despărțirea de Vasile Latiș, în revista Mișcarea Literară, Bistrița, nr.3/2007, pag. 83
} 
oximoronice, aş zice, de negură şi lumină, de smerenie blândă şi vehemenţă deconcertantă, de resemnări beatice și răzvrătiri teribile. Un amestec de înţelepciune angelică şi o obscuritate neguroasă, cvasidemonică: traseul de creator poetic al lui Latiş reproduce în linii mari, previzibil poate, antinomiile constituive ale fiinţei poetului. Un debut revuistic matur şi promiţător, cu un grupaj de poezii onorabile, în revista Familia de la Oradea, la începutul anului 1967, după care o nedorită condiţie provincială, greu suportabilă şi deplânsă vehement de nenumărate ori, îl face să-şi amâne cu (incredibil!) nu mai puţin de trei decenii debutul editorial. Acesta se consumă la o vârstă aproape senectă, cu volumul de versuri Odihnă Rostitoare, publicat în anul 1996, la editura băimăreană Proema, aceea care îi va tipări mai apoi majoritatea cărţilor din uluitoarea salbă de producţie lirică ce a urmat. Aceasta s-a alcătuit din nu mai puţin de 12 volume de versuri, publicate până în 2007, anul morţii sale, la care se adaugă un volum postum, îngrijit de prieteni devotaţi, ceea ce înseamnă că ritmul apariţiilor editoriale a fost de cel puţin o carte pe an. Cadenţa creatoare neobişnuită, greu de explicat pentru un poet care debutează în volum la vârsta de 63 de ani, dacă excludem (şi cred că avem argumente să o facem) ipoteza că, la momentul apariţiei primei cărţi, poetul ar fi avut o rezervă consistentă de producţie de sertar. Nu credem că a fost cazul. Cărţile lui Latiş par scrise „dintr-o suflare”, o succesiune unitară de producţii lirice mature, târzii, aparţinând - cum s-ar spune convenţional - aceleiaşi vârste de creaţie. De această realitate, a fluxului abundent de poetizare din ultimul deceniu de viaţă (căruia probabil receptarea entuziastă a volumelor de poeme, mai ales pe plan local, i-a sporit cadenţa şi intensitatea) se leagă, în bună parte, atât virtuţile cât şi neîmplinirile poeziei lui Latiş. Impresia copleşitoare a lectorului este că, de la prima la ultima carte, parcurge un unic text, cu variaţii insignifiante şi minime diferenţe de formulă, cu absenţa evidentă a unor vârste sau etape de creaţie ceea ce elimină, în bună măsură, trăirea, efectivă sau afectivă, prezenţa în text a unui eu liric factual, retras parcă deliberat în umbră pentru a-i face loc, cu magnificenţă, eului intelectiv, sentenţios şi grav meditativ. Am spune că eul creator nu este la Latiş o conştiinţă participativă, inserată în filigranul textului poetic, ci o conştiinţă de reflectare, oarecum exterioare desenului textual. De aici, tonul general al poeziei: eminamente reflexiv şi grav-sapienţial ori abrupt sentenţios, ceţos oracualar ori vizionar-orfic, subsumat unei lirosofii personale în care eul real este greu detectabil sub veşmântul tenebros al livrescului. Suntem în prezenţa unei conceptualităţi în bună măsură opacizate de vagul privirii poetice ori al unei simbolistici mitico-filosofice aproximative ori incriptate sub cadenţa gravă a rostirii. Poate că în această realitate își are temeiul impresia de profunzimi impenetrabile şi de adevăruri esenţiale, spuse cu aerul tonului definitiv. Când din nestăvilita magmă poetică a textului unic, se ivesc suprafețe insulare mai calme, în care sinele îşi permite luxul privirii 
directe înspre real, a contemplaţiei nemediate de abstracţiuni filosofice ori de nebulozităţi mitico-cosmogonice, poezia iese în câştig cert, înfăţisând nu puţine tablouri textuale esenţializate, de mare puritate şi forţă a rostirii.

În tot cuprinsul liricii sale însă, Latiş e un aed, un bard cu ritmuri sacadate şi inflecţiuni grave, cu obsesia permanentă a rădăcinilor/ obârşiilor/ izvoarelor, adică a unui originar supracategorial din care izvorăsc apoi, ca într-o cosmogonie permanent reinterată şi rememorată, arhei, monade şi numeni, adică tot atâtea grăunţe vitale de sacru ale lumii. Toate aceste elemente de plasmă arhetipală sunt mereu evocate, obsesiv chiar, în ipostaza lor primordială, în tonalitate gravă, criptică şi misterioasă. Despre gravitatea rostirii sale poetice - o marcă stilistică ce nu poate fi dezlipită de creaţia sa, funcționând ca o diferenţă specifică majoră - Latiş crede, aşa cum mărturiseşte într-un interviu ${ }^{3}$ - că ea vine din structura esenţialmente tragică a fiinţei şi a interiorităţii sale: „Nu, eu nu sunt artist; artiştii au suflet ludic, se iubesc pe sine; eu sunt un suflet tragic (s.n.). Eu sunt creator. Imi plac oamenii neartistici."

Să admitem că, fiinţial, Latiş e într-adevăr o natură tragică, sfâşiat între un real pe care-l consideră insuficient şi neîncăpător şi percepţiile vii şi acute ale unei transcendenţe foarte prezente care-i modelează decisiv sentimentele şi trăirile. Expresia lirică a acestor stări de fapt este însă una mai puţin limpede şi semnificantă, slujită de o voce poetică cam imprecisă şi nebuloasă, laxă şi şovăielnică adeseori, prolixă până la verbozitate în dese rânduri, fără a reuşi, decât rareori, să ordoneze o viziune poetică unitară şi congruentă, de timbru poetic egal. Adeseori lectorul avizat are impresia acută că din text s-ar putea decupa nuclee poetice de mare frumuseţe, profunzime şi organicitate, care însă, în ansamblul construcţiei lirice, sunt copleşite ori sufocate chiar de emisii textuale ceţoase, cu vag aer oracular, de aluviuni ori de un limbaj poetic ambiguu, insuficient decantat sau subsumat unei viziuni coerente. Când însă, în clipele faste ale poetului, tentaţia filosofării ostentative şi a unei înceţoşate şi aproximative sapienţialităţi, a tonului grav, cu inflexiuni sacerdotale, ostentativ căutate, sunt reprimate sau măcar atenuate, „miezul” viziunii poetice se lămureşte spectaculos, cu irizări elegiace vibrante şi convingătoare, amintind ca şi în alte rânduri de meditaţia rilkeană cald amăruie, rostită firesc, cu discreţia şoaptei: „Toamna poate să fie domoală, umbrele nucului/ subţiratice, ochiul tău liniştit către ziua din/ urmă. Focul în vatră, uituc; satul brun în valea/l adormită. Din vara-vară, ce-a mai rămas? E timpul,/ acum. Aşteptăm. Aşteptăm ce n-a mai venit şi are/ să vină-ntr-o zi: fructele, coapte, pâinea şi vinul, pel/ masă, aşteptăm mânia cerească să treacă odată cu noi./ raze despică. Se scutură alunul tot. Pământul se/ arcuieşte/ pe umăr, uşor, păsări

3 Poeți români contemporani, Interviu cu Eva Aqui, 2002, publicat în volumul Vasile Grigore Latiș, Cartea inocenței, Editura Grinta, Cluj-Napoca, 2011 
se duc către sud mai fierbinte.// E timpul acum... Am fost primitori. Ca din nimicl ne-am născut - din pietre şi arbori, din gură del râu, din imnici păstori, de demult şi drumul întors/ către casă. Toamna poate să fie domoală şi singură - / una, ca noi. (Variantă de toamnă)

Temele recurente ale liricii lui Latiș țin de tot atâtea obsesii, angoase ori edificări structurale ale psihismului său de adâncime, unele tulburi și difuze, așa cum am mai amintit: căutarea impulsului primordial și a reperelor esențiale ale ființei, traduse printr-o adevărată obsesie a originilor și a „,izvoarelor”. Aici își au sursa miracolul rodului și al fertilității universale, epifaniile sacrului, erosul care de cele mai multe ori stă în binom freudian cu moartea, spectrul ,fratelui nenăscut”, privit ca un alter personal complinitor, percepțiile vagi ale unei stări de entropie a lumii, de haos primordial, peste care creația încă nu și-a așezat ordinea, și așa mai departe. Sunt teme vădit majore, cărora poetul le acordă o importanța nu lipsită de o oarecare emfază și de aceea convoacă în tratarea lor un limbaj înalt, prețios chiar, gnomic și oracular, cu note de orfism ori de metru antic. Totul se consumă, desigur, în prezența modelelor, care uneori sunt atât de evidente, încât nu putem înlătura nici impresia de pastișă, într-atât de vădită este suprapunerea în spirit și tonalitate cu originalul (ba adesea chiar cu expresia și cadența traducerii românești a acestor modele!), la nivelul evidenței fiind „,sonurile" hölderliniene sau rilkeene.

Încă din primul său volum, Odihnă Rostitoare (1996), sentimentul obârşiei, al locului predestinat de ivire în lume pentru ,cel bine născut”, ori al vetrei sacre, încercarea de percepere ori de ,adulmecare” intuitivă a izvorului, a pulsiunilor originare, traduse în Logos ori în stră-cântul ancestral, devin o preocupare constantă: „Răsfrânt în auz! Când se-ntoarce către soare - răsare/ Și cu raze-adunate noaptea îl ceartă întruna, / $̂ l$ poartă, ca pe-un orb dus departe de mână pel cărările timpului. Dar bucuros el coboară la vatră/ și niciodată nu-și uită obârșia cel bine născut,/ când prunci creează, și marea-nflorită și oameni/ dar mai presus iubește norocul celui ce învață îndelung/ și rămâne la sine." Din păcate însă, ca în atâtea alte dăți, în continuarea configurării acestui tablou al originarității, discursul poetic rătăcește dezorientat, chircindu-se întrucâtva sub palele de vânt rece ale impreciziei și obscurizării discursului: „Drept e, însă, și-afară vădeștel și ucigașul trece prin vântul de vară spre coastele/ abrupte ale fluviului,/ spre Asia poate sau către blânde furtuni ale anului." (Zece meditații minore)

Ajunși în acest punct, nu putem să nu constatăm că poezia lui Latiș ar avea numai de câștigat printr-un necesar și dezirabil proces de antologare. Poate că acest lucru ar fi fost necesar să fie făcut de autorul însuși, printr-o mai mare exigență de selecție și de finisare a unor texte cuprinse în volumele care s-au succedat într-o sarabandă amețitoare - cel puțin câte unul pe an - în ultima decadă de viață a poetului. Un filtru critic personal 
mai dens ar fi putut îndepărta acele producții ori aluviuni textuale care sufocă uneori poezia și, în același timp, ar fi reușit să îndepărteze monotonia vocii poetice și impresia stăruitoare de „variațiuni pe aceeași temă” (este chiar titlul unuia dintre volumele sale!) cu care rămâne invariabil lectorul tenace al tuturor celor 13 volume de versuri ale poetului. Misiunea unui viitor antologator nu va fi una ușoară, dar odată făcută cu acribie, ea se va dovedi benefică pentru conturarea unei fizionomii poetice cât mai clare și mai congruente, a lui Vasile Latiş.

Există în poezia lui Latiș sugestii multiple ale inițierii prin cuvânt, ale accesului într-un teritoriu al înțelepciunii, al tainelor și al revelației, al apropierii de alcătuiri imuabile și de adevăruri esenţiale. Tăcerea, adică absența numelui și a numirii, face parte și ea din această sui-generis hermeneutică a cuvântului, foarte proprie poetului. Tăcerile acestuia par uneori mai încărcate de sens și mai dramatice decât rostirea însăși: „,Mai incet... De-ai fi fost cumva fericit la-ntrecerile/ sacre, ori dacă numele tău a fost strigat la/ Nemeea, în dealul cu coamă lată, până departe,/ străbătător. Nu lăsa inimă chiparoșii! Nici valea/ roită. Nu munții profetici, stihia ta sub picior/ mergător, iar cei credincioși către Delphi indreaptăl/ să afle răspuns, să asculte ce Zeul într-înșii cuvântăa." (Andante religiosso)

În forma sa orfică, eteric sacrală, cuvântul se sublimează în cântec, privit ca vehicul intermediar între profan și sacru, între om și zeu, ca în imnurile de solemnă gestualitate ale lui Hölderlin, un model poetic ce nu poate fi tăgăduit: „Același aceluiași gând și multe-ar putea tâlcui/ ințelepții. Într-adevăr ei ajung până la cuvântul/ din urmă dar nu-i al lor și nici nu trebui să fie./ Acolo, la răscruce, Oameni și Zei se despart:/ Plinele zodii pier și renasc prin îndurarea aceasta.// Dar cântecul, el, se coboară la morți și-i cunoaștel din moarte după zâmbetul mamei. Copiii năzuit-au,/ frumoase femei și poeți, și ceice se desprind acum// lângă o mare străină. Ei pot: și-ades se roagă/ alături de tine. Cântecul, el, se coboară la morți/ și fiecare se are pe sine." (Către...) Fără îndoială, lui Latiș îi lipsește onirismul prodigios și revelația frisonantă a preromanticului german. Astfel că, neavând suficient suflu pentru a închega viziuni revelatorii coerente, scriitura sa îl obligă pe exeget să se pună în situația derutantă de a putea admira imagini disparate, de mare frumusețe metaforică, rătăcite într-un melanj pâclos de concepte filosofice aproximative, ca și cum ar privi cu încântare o floare plăcut mirositoare, răsărită dintr-un grohotiș arid. Formula elegiacă a poemului este cea care rezonează cu sensibilitatea introvertită, cu interiorul poetului, plin de magme profunde și neliniștite, expansive uneori, cu conștiința sa esențialmente reflexivă și cu tonul solemn, de litanie vastă, de complainte nesfârșită, proprie măștii permanent îndurerate pe care poetul o poartă pe chip. În lungi secvențe ale sale, poezia pare un nesfârșit lamento, o orație funebră, rostită pe ton sumbru care exclude orice posibilitate de înseninare: „Tine-mă sub privire, scufundă-mă într-apele aceste prea mărite 
cu gândul. Adă-ți aminte de mine; mă/ uită.// Dar pe deasupra plutind-alb guler și galben guler/ ne-mbie./ Vaier din vaierul luminii și el coborî în devălmășia/ abisului, tras în mal roditor, intr-altă viață/ pe care noi n-am trăit-o, un veac suspendat/ între un martie grăbit și celălat septembrie/ în care noi sărbătoream o blândă absență cu/ mâinile lăsate jos, în deșert. (...)/ lasă-mă pe mine, un copil, să le zoresc cu numele/ către-o zi ce-ntârzie. Lasă-l să le numească/ cu numele pe cel ce-i gata de propria moarte./ scapă-mă de ințelesul acesta... de celelalte câtel stau în puteri și vin amenințător din mine spre mine:/ din dosul golului mai ascuns."

Uneori fervoarea imagistică e aproapă ebrietară, un soi de dicteu automat, de sorginte suprarealistă, care face ca suprafața textuală să fie atât de încâlcită și de răvășită, încât textul devine entropic, aproape un galimatias: „Ce estel această pură-aparență în noi mai ascunsă/ decât au stat vreodată vădită, Ziua și Noaptea,/ urmându-și, când floarea de colț demult s-a pierdut? Iar în acest Neunde, de-ndată limitatul aproapelui/ său de parcă vederea ar fi de ea însășil orbită și, după salt, căderea mereu repetată,/Unde - ill port în inimă - răsare acel trecător/acela care a păstrat adânc nimicitul/ în inimă fără grai și în căutătura mai blândă,/ trecătorul, mai trecător decât valul care vine/ din urmă?" (Elegia I)

Mai coerent, mai sintetic și implicit mai elaborat din punct de vedere al poiesisului, adică al capacității de textualizare a ideii, sunt evocările și invocările Diotimei, convocată în linia aceleiaşi filiaţii holderliniene, în temeiul acelorași „mitologicale” (titlu de poem!), pe care le reinterpreta frecvent și poetul german. Transgresând ușor dinspre canavaua mitologică spre concretul experienței erotice personale, poetul are clipe de grație când viziunea sa dobândește forță și plasticitate, iar vocea lirică devine vibrant patetică și persuasivă, împregându-ți-se în auz cu sugestii stăruitoare de senzualitate imnică: „Mă vei iubi-ntr-o zi, iubire grea și mândră -asemeni/ mie, azi, dar n-aș voi s-o știu. Prea doare totul: ochi și mână,/ cuvânt, și drum alături, și noapte și lumină, o vatră arsă,/ și iarbă ruginie, pe-nserat, şi foc uituc pe câmp departel prea s-au născut ca să nu țină. Să fugi de toți: să temi acestel blânde morți." (Socrate se plânge după Diotima XXXXVIII)

Pe acest teritoriu al liricii erotice, Latiş se înfățișează cu certe reușite, propunând o poetică discretă, șoptită, cu oglindiri meditative, caldă și convingătoare, a discursului amoros. Vocea sa dobânește forță și credibilitate, iar artefactul poetic, ca și cadența rostirii, sunt mult mai bine strunite și echilibrate. Poetul demonstrează aici o remarcabilă naturalețe, a cărei absență am deplâns-o uneori în alte teritorii ale liricii sale.

Invocarea sau evocarea iubirii par deopotrivă că-i procură lui Latiș o stare de extază, de jubilație interioară pe care o convertește liric în recitative meditative, ușor adumbrite evocativ, de incontestabilă frumusețe: „Iar tu, odată, e mult de-atunci - mi-ai spus: O,/ nu mai vorbi despre noi, de-a 
dreptul, nu mai vorbi/ recunoaște primejdia cea mare în cuvinte, le lasă,/ nu le iubi, destinul nostru nu-l mai vorbi de azi/ înainte. Dar plin de tăcerei pământul, am spus, piatra/ se roagă la steaua de sus și n-are cuvinte, țipă o/ pasăre singură-n zare-n auz, o mie de ani așteaptă/ lumea frumoasă și sfântă să se poată rosti, să fiel ființă. Atunci ea astfel grăi: De le numești au să moară/ și ele-ntr-o zi, au să moară și uite, au să ne uite/ pe noi într-o zi cele sfinte. E mult de-atunci: și vorba-i/ era aşezată cuminte.(Socrate se plânge după Diotima, variante II)

Asistăm în lirica lui Latiş la un spectacol al eului aflat în permanent proces de statuare și de căutare de sine. Obsesia originarului despre care am vorbit, interogațiile și permanenta raportare la sacru, prilejuiesc o devoalare a sinelui, surprins într-o succesiune de ipostaze din care nu lipsesc avatari precum fratele nenăscut, băiatul, străinul, celălalt, o sumă de alteri și dualități ființiale care pot sugera o oarecare formă schizoidală de percepție a existenței: trăitul aici se complinește ireductibil cu trăitul dincolo: „Eu însă vorbesc aici de cel ce-și păstrează/ cealaltă viață a lui acum nimicită și nu se teme/ să stea sub catarg desfrunzit (...)// De mine vorbesc și de tine de-odată, la judecată rămași./ De vii și de morți cum se-ntâlnesc la vaduri/ de ape și se-nbie să bea deopotrivă din val." (Plâns I) Eul își conține invariabil geamănul eteric, o prezență adesea funebră, dătătoare mai degrabă de frisoane, decât aducătoare de echilibru: „Unul a privit întru sine - și ce a văzut?/ Un altul, acolo, șezând. Un băiat răposat,/ de demult, și se minuna de somnul frunzișului,/ de taina întunecată din ape. În cripta recel/ novicele aprinde făclii de aur." (Portret I)

Cât despre relaţia poetului cu sacrul, mereu reiterat în ipostaze textuale pregnante, ea dezvoltă o întreagă imagerie a inefabilului ori a prezenței divinului în lume, de la rădăcinile-sensuri, la ochiul închis înăuntru, luminând înțelesuri tainice ori la foșnirile abia perceptibile ale Logosului întemeietor.

Poet înzestrat, dând uneori impresia că este atins de aripa harului, dar adesea inegal și fără o logică a devenirii personalității sale creatoare, uzând de o formulă textuală care a suferit schimbări minime pe parcursul ultimului său deceniu de creație, acela în care și-a publicat cărțile, Vasile Latiș se înfățișează judecății critice pe muchia, întotdeauna paradoxală, a monedei cu două fețe. De o parte scriitorul (etnologul, eseistul și poetul), cu realizări certe, mereu la nivel de onorabilitate și uneori atingând excelența, de cealaltă parte, gânditorul de latentă virtualitate și de profunzimi ale cugetării, a cărui prodigiozitate a rămas doar întrezărită. La nivelul atelierului său de creație poetică, Latiș a fost uneori prea îngăduitor cu sine, lipsit de o exigență care 1-ar fi putut servi critic, ferindu-l de o seamă de inegalități ale scrisului. $\mathrm{Nu}$ ne îndoim că posteritatea va face cuvenita și necesara operație selectivă, punând în valoare, o dată în plus, caratele creatoare ale personalității scriitorului. 